СУЧАСНИЙ СТАН ТА ПЕРСПЕКТИВИ РОЗВИТКУ ДЕРЖАВНОГО ФІНАНСОВОГО АУДИТУ ДІЯЛЬНОСТІ СУБ'ЄКТІВ ГОСПОДАРЮВАННЯ ДЕРЖАВНОГО СЕКТОРУ ЕКОНОМІКИ

\title{
CURRENT SITUATION AND PROSPECTS OF DEVELOPMENT OF THE STATE FINANCIAL AUDIT OF ACTIVITIES OF PUBLIC ECONOMY SECTOR
}

УДК 657.6

https://doi.org/10.32843/infrastruct37-111

\section{Савченко А.М.}

к.е.н., доцент,

доцент касредри аудиту

та економічного аналізу

Університет державної фріскальної

служби України

Поляков В.М.

студент

Навчально-науковий інститут обліку, аналізу та аудиту

Університет державної фріскальної служби України
Зараз для України дуже важливо мати достовірну та об'єктивну інсрормацію про есрективність використання державних коштів та майна бюджетними установами. Ефективне управління державними фрінансами - основа стабільної економіки країни, ї зростання та безпеки. Адже в сучасних умовах ринкової економіки, коли Україна ввійшла до Асоціації, тісно співпрацює з ЄС та МВФ, важливо запровадити міжнародні стандарти обліку та практику проведення державного аудиту, що сприятиме конкурентоспроможності держави на міжнародному ринку. Модернізація державних фрінансів обов'язкова умова євроінтеграційних процесів та майбутнього економічного розвитку України та їі фрінансової незалежності та безпеки. 3 погляду на збільшення тіньового сектору економіки, та безпосередньо випадків шахрайства та розкрадання бюджетних коштів, державного майна. Державний фрінансовий аудит, покликаний покращити рівень фрінансової дисципліни у використанні бюджетних коштів. Створення дієвої та прозорої системи контролю за використанням коштів бюджету - важлива умова забезпечення зростання української економіки. Оскільки Україна знаходиться на стадії розбудови ринкових відносини, то державний фрінансовий контроль відіграє вирішальну роль в забезпеченні фрінансової дисципліни. Це один із способів наповнення державного бюджету, спосіб економії держмайна та інструмент боротьби із економічними злочинами.

Ключові слова: державний фрінансовий аудит, державне майно, бюджетні кошти, бюджетні установи.

Сейчас для Украины очень важно иметь достоверную и объективную информацию об эсрсрективности использования государственных средств и имущества бюджетными учреждениями. Эфрфьективное управление государственными финансами - основа стабильной экономики страны, ее рост и безопасности. Ведь в современных условиях рыночной экономики, когда Украина вошла в Ассоциацию, тесно сотрудничает с EC и МВФ, важно внедрить международные стандарты учета и практику проведения государственного аудита, будет способствовать конкурентоспособности государства на международном рынке. Модернизачия государственных финнансов - обязательное условие евро интеграционных процессов и будущего экономического развития Украины и ее фринансовой независимости и безопасности. С точки зрения увеличения теневого сектора экономики, и непосредственно случаев мошенничества и хищения бюджетных средств, государственного имущества. Государственный фринансовый аудит, призванный улучшить уровень фринансовой дисциплины в использовании бюджетных средств. Создание действенной и прозрачной системы контроля за использованием средств бюджета - важное условие обеспечения роста украинской экономики. Поскольку Украина находится на стадии развития рыночных отношениях, то государственный фринансовый контроль играет решающую роль в обеспечении финансовой дисциплины. Это один из способов наполнения государственного бюджета, способ экономии госимущества и инструмент борьбы с экономическими преступлениями.

Ключевые слова: государственный фринансовый аудит, государственное имущество, бюджетные средства, бюджетные учреждения.

It is now very important for Ukraine to have accurate and objective information on the efficiency of use of public funds and property by budgetary institutions. Effective management of public finances is the basis of a stable economy of the country, its growth and security. After all, in the current conditions of a market economy, when Ukraine joined the Association, closely cooperates with the EU and the IMF, it is important to introduce international accounting standards and practices for conducting state audits, which will contribute to the country's competitiveness in the international market. The author analyzed the effectiveness modern forms of control in the public sector of the economy of Ukraine. Modernization of public finances is a prerequisite for European integration processes and the future economic development of Ukraine and its financial independence and security. In view of the increasing shadow economy, and directly the cases of fraud and embezzlement, state property, the state financial audit is intended to improve the level of financial discipline in the use of budgetary resources and to prevent fiscal misuse and crime. An important requirement to build a modern system of public financial control at all levels of management is to exercise control based on ensuring clear interaction and coordination of efforts all participants of financial and budgetary relations for solving problems of state financial control. Implementation of measures to improve control efficiency and responsibility for complying with budget legislation should be exercised by continuing to improve its financial control procedures compliance with budget legislation and implementation of the mechanism monitoring and evaluating the effectiveness of their control bodies authority. Creating an effective and transparent system of control over the use of budget funds is an important condition for ensuring the growth of the Ukrainian economy. As Ukraine is at the stage of building market relations, state financial control plays a decisive role in ensuring financial discipline. This is one way of filling the state budget, a way of saving state property and an instrument for combating economic crimes.

Key words: state financial audit, state property, budgetary funds, budgetary institutions.

Постановка проблеми. В Україні величезна кількість державних підприємств та установ, більшість 3 яких працює неефективно або знаходиться у стадії ліквідації. Всі вони вимагають фрінансування з дер- жавного бюджету, але доцільність та ефективність використання ними коштів потребує фрункціонування якісної та сучасної системи фрінансового контролю, складовою якої є державний фрінансовий аудит. 
Аналіз останніх досліджень і публікацій. Діяльність державного сектору вивчали О.В. Дейнека, М.О. Кравченко, С.В. Свірко тощо, а проблеми та перспективи впровадження державного фрінансового аудиту в діяльність контролюючих органів досліджували О.Ю. Пушкарьова, О.О. Репетько, І.Б. Стесанюк, Є.М. Мних, Т.М. Письменна та ін.

Постановка завдання. Проаналізувати сучасний стан, порядок впровадження та проблеми. Оцінити перспективи розвитку державного фрінансового аудиту в діяльності ДАСУ. Систематизувати та закріпити теоретичні знання з державного аудиту.

Виклад основного матеріалу дослідження. Більшість вітчизняних учених підкреслюють, що державний аудит - один з видів державного фрінансового контролю, який запобігає фрінансовим порушенням суб'єктами державного сектора економіки, дозволяє ефективно використовувати бюджетні кошти та правильно вести їх облік. Отже, мета проведення аудиту - перевірка законності та есрективності використання державних ресурсів. Він використовується для перевірки та аналізу показників фрінансової, операційної та господарської діяльності, тобто, об'єкт аудиту - державне підприємство, яке отримує кошти з бюджету. Для досягнення поставленої мети потрібно виконати наступні завдання: оцінити рівень управління; виявити ризик і джерел підвищення есрективності управління; підготувати рекомендації для покращення показників діяльності, усунути порушення та недоліки та попередження в майбутньому.

При цьому джерела інформації аудиту: нормативно-правові акти, засновницькі та розпорядчі документи, фрінансова і статистична звітність, матеріали попередніх перевірок, бухгалтерські документи, договори та контракти підприємства [4].

Методологічні особливості аудиту бюджетних підприємств полягає в вивченні, передусім, факторів ризику, пов'язаних з використанням коштів бюджету. Крім цього, кожен фрактор ризику має бути досліджена на відповідність законодавчонормативним актам, виявлена їх обґрунтованість i доцільність, а також проведено порівняння запланованих показників з фактичними. Після цього аудитор має визначити ступінь впливу порушень на фрінансово-господарську діяльність. При цьому аудитору важливо виявити зовнішні і внутрішні фактори ризику.

Незважаючи на ефеективність використання такого виду аудиту для перевірок державних підприємств, його розвиток тільки розпочався, а сучасний стан має ряд проблем та невирішених організаційних питань.

Тобто, державний аудит потребує реформування і створення дієвої та сучасної системи, для чого необхідно: базу;

- розробити концепцію аудиту та інсрормаційну
- вдосконалити нормативно-правове забезпечення;

- розробити і впровадити нові стандарти і методи;

- розподілити фрункції і відповідальність органів в сорері контролю і аудиту;

- законодавчо закріпити за Рахунковою палатою статус вищого органу державного аудиту;

- покращити рівень підготовки та кваліфікації аудиторів;

- розробити критерії, які допомогли б оцінити ефрективність аудиту.

Тобто в сучасних умовах ринкової економіки росте значення державного фрінансового аудиту, який сприяє підвищенню ефективності діяльності державних установ, використання бюджетних коштів та удосконаленню системи управління.

Державна аудиторська служба (ДАСУ) - орган виконавчої влади, який реалізує політику держави у галузі фрінансового контролю [1].

Для визначення пріоритетних напрямів удосконалення порядку державного аудиту, спочатку треба проаналізувати його сучасний стан та виявити позитивні та негативні тенденції діяльності Аудиторської служби.

Діяльність ДАСУ визначається низкою законодавчих актів: Бюджетним кодексом, ЗУ від 26.01.1993 № 2939-XII «Про основні засади здійснення державного фрінансового контролю в Україні», Постановою КМУ від 03.02.2016 № 43 «Про затвердження Положення про Державну аудиторську службу України» та іншими нормативно-правовим засадами [12].

У період 2007-2017 років ДАСУ здійснено 1305 аудитів діяльності, 489 аудитів бюджетних установ та 808 перевірок виконання бюджетних програм (рис. 1) [9].

У 2016 році спостерігається зростання питомої частки кількості аудитів у загальній кількості контрольних заходів з 30\% на початку року до $41 \%$ наприкінці року. Тобто, фрінансовий аудит починають застосовувати частіше. Це сприяє підвищенню ефективності діяльності установ та організацій.

Основні порушення законодавства, які виявляють органи ДАСУ при проведенні заходів: нецільові витрати державних ресурсів, незаконні витрати та недостачі [2].

Під час аудитів у 2018 році досліджено 679,5 млрд грн фрінансових ресурсів та виявлено порушень на 15,9 млрд грн. Найпоширеніші порушення і недоліки:

- неефективне витрачання коштів та майна 7,5 млрд грн;

- упущені вигоди - 8 млрд грн;

- незаконне використання ресурсів та їх втрата - 340,7 млн грн;

- порушення, які можуть викликати втрати в майбутньому - 68,9 млн грн. 


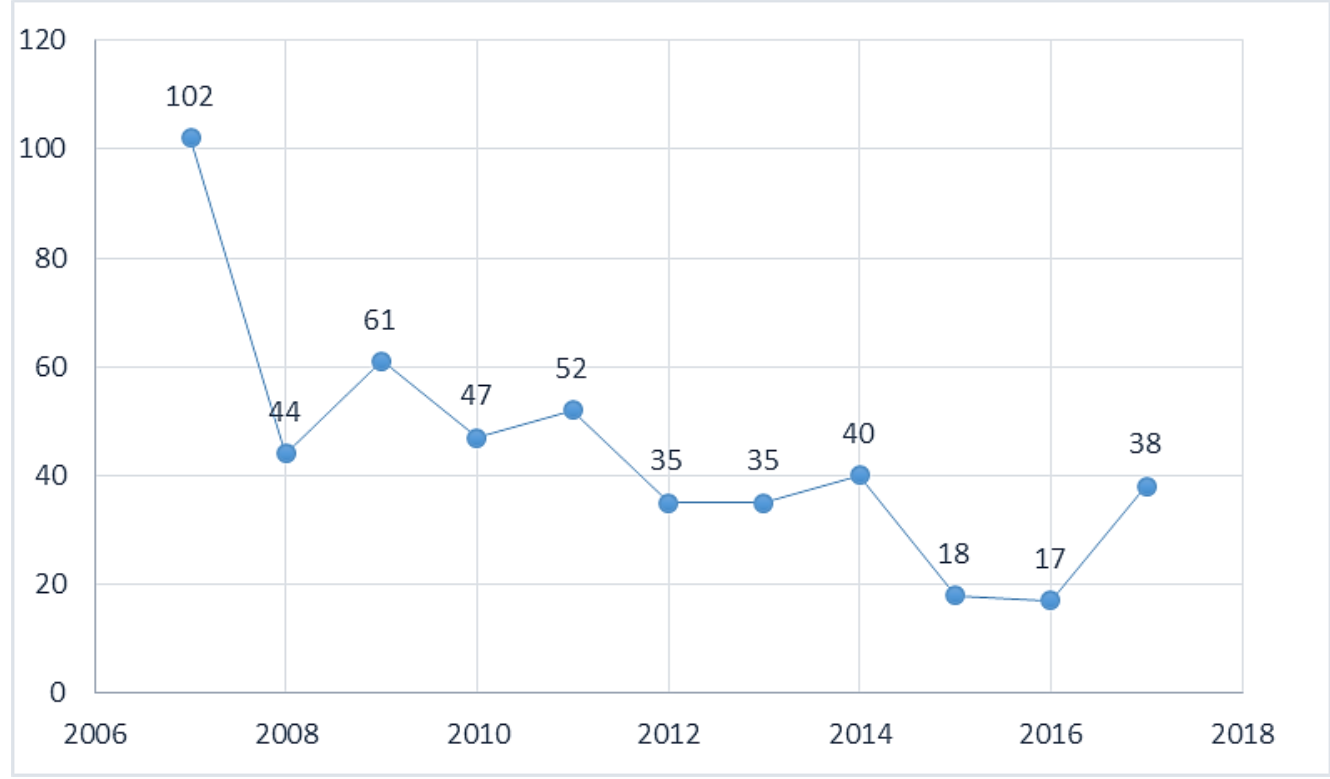

Рис. 1. Кількість державних фрінансових аудитів діяльності державних підприємств у динаміці, 2007-2017 роки

Також аудиторською службою упереджено втрат на 463 млн грн, складено 596 аудиторських звітів та надано 3,9 тисяч рекомендацій [3].

Отже, кількість порушень, виявлених під час перевірок та аудитів ДАСУ, зменшується з кожним роком. Кількість нецільових витрат у 2014 році становила $160.5 \mathrm{млн.} \mathrm{грн,} \mathrm{а} \mathrm{у} 2017-81,1 \mathrm{млн.} \mathrm{грн,}$ тобто зменшились вдвічі. Незаконні витрати підприємств зменшились на 2765,5 млн грн, а недостачі - на 277,5 млн. грн. Тобто $€$ економічний ефрект від запровадження фрінансового аудиту, як виду контролю. В 2017 році до бюджету відшкодовано 787,9 млн. грн. - як результат діяльності ДАСУ.

У 2015-2016 рр. у структурі контрольних заходів лідирує кількість проведених ревізій - 94\%, фрінансових аудитів - 3,5\%, моніторинг держзакупівель - 2,5\%. Така ситуація не відповідає вимогам реформування системи аудиту та фінансового контролю.

Тобто впровадження та використання державного аудиту має низку недоліків:

- не визначені загальні принципи, процедури та методи аудиту;

- на низькому рівні знаходиться інорормаційне та програмне забезпечення;

- чітко не визначені фрункції, права, обов'язки аудиторів та їхня відповідальність за належне проведення аудиту;

- немає принципів і критеріїв з вибору об'єкту аудиту;

- не визначено, по якій фрормі мають складатися вихідні документи за результатами перевірки та для кого вони призначені взагалі;

- відсутні фрахівці з належним рівнем професійної підготовки;
- неузгодженість та протиріччя у нормативнозаконодавчих актах [7].

Зараз Україна переходить від ревізій до нефріскальних видів та методів контролю. Їхня мета запобігання недолікам в діяльності і профрілактика порушень, а не виявлення та покарання винних. Тому державні фрінансові аудитори повинні мати високий освітній та фаховий рівень.

Отже, сучасні форми контролю - ревізія та перевірки, неспроможні завадити фрінансовим порушенням і неактуальні для сучасних потреб. Аналіз даних про результати діяльність органів Фінансової інспекції у 2007-2011 роках, тобто до впровадження методики проведення державного фрінансового аудиту, свідчить про зростання кількості та обсягів порушень. [10].

Все це свідчить не про необхідність посилення контролю, а про застосування нових підходів, які б враховували сучасні тенденції розвитку фінансової галузі та економіки країни.

Майже 10 років тому в Україні було започатковано державний аудит діяльності суб'єктів господарювання бюджетних підприємств для виявлення упущень, проблем і недоліків не лише фрінансового характеру, а й організаційного та законодавчого, які вливають на результати діяльності в внаслідок помилкових рішень, збиткових договорів, нецільового використання бюджетних коштів, реалізації товарів за зниженими цінами. Тому економічний ефект від такого виду контролю навіть вищий, ніж від санкцій та штрафрів ревізії [4].

Як підкреслювалось неодноразово, аудит більш прийнятний та сучасний метод фрінансового контролю, ніж ревізія. Більшість країн світу вже давно використовують фрінансовий аудит та аудит 
еорективності. Наприклад, країни ЄС уніфікують законодавство відповідно міжнародним вимогам та директивам [6].

Згідно з міжнародною практикою, аудитор не повинен шукати помилки та нестачу коштів, як зараз, на жаль, проводиться фрінансовий аудит в Україні. Досвід зарубіжних країн стосується, в першу чергу, підтвердження бухгалтерських звітів незалежними аудиторами [8].

Отже, Україна має вдосконалити свою систему проведення фрінансовий аудит згідно міжнародних стандартів, одним 3 яких є Міжнародний стандарт аудиту 200 «Мета та загальні принципи аудиту фрінансових звітів». Його мета - достовірність звітності.

На відміну від інших країн, в Україні недосконале законодавство та відсутній основний закон, що регулює діяльність аудиторів. Існує велика кількість постанов, наказів, методик, розпоряджень та законів, що доповнюють один одного, а прийняття нових скасовують чинність попередніх. Таким чином, бувають ситуації, коли на початку проведення державного фрінансового аудиту фрахівець складає програму аудиту та перевіряє діяльність підприємства відповідно до одних нормативноправових актів, а рекомендації складає згідно вже нових прийнятих законів.

Отже, система управління державними установами неефективна, не відповідає вимогам національної економіки та не виконує соціальні та стратегічні функції, які на неї покладені, а тому потребує ресрормування.

Важливо пам'ятати, що головне завдання фрінансового аудиту - допомогти підприємству правильно вести облік та ефективно і за призначенням використовувати кошти державного бюджету.

Таким чином, підводячи підсумки, можна окреслити основні проблеми державного фрінансового аудиту:

- відсутність стандартів аудиту;

- відсутність дієвих методологічних рекомендацій;

- недостатня кількість кваліфікованих кадрів;

- низький рівень профрілактики та недоліків в діяльності;

- відсутність спеціального програмного забезпечення;

- протиріччя і відсутність узгодженості в законодавчо-нормативних актах;

- низька відповідальність учасників бюджетного процесу.

Під час реформування фрінансового аудиту слід враховувати виявлені проблеми та недоліки та всю увагу зосередити на їх виправленні. А також на впровадженні міжнародного досвіду в аудиторську діяльність [9].

Також потребує вирішення нмизка організаційних питань: кількість перевірок за рік, бо вони не повинні перешкоджати виробничій діяльності підприємств та установ, розподіл обов'язків працівників і встановлення меж їх повноважень. Законодавча база діяльності ДАСУ має відповідати вимогам ЄС до управління державними фрінансами, а також базовим засадам Міжнародної організації вищих органів контролю державних фрінансів.

Отже, основні напрями реформування системи аудиту бюджетних установ: формування нових та вдосконалення існуючих методів контролю та вдосконалення організаційних структур фрінансового аудиту.

Тому необхідно:

- розробити комплекс заходів щодо офрормлення звітів фрінансового аудиту, які б відповідали чинним нормативним актам;

- застосовувати електронні технології та спеціалізоване програмне забезпечення;

- ввести в дію систему електронного обміну документами.

Всі вищеперелічені заходи та пропозиції важливо застосовувати та впроваджувати в комплексі для вдосконалення та підвищення ефективності проведення державного фрінансового аудиту та контролю взагалі [2].

Перші кроки у вдосконалення діяльності ДФІ, КРУ та ДАСУ зроблено. Постановою КМУ від 28.10.2015 № 868 створено Державну аудиторську службу шляхом реорганізації Державної фрінансової інспекції. У 2016 році створили п'ять офрісів ДАСУ $з 27$ ДФІ.

У перспективі, для створення ефективної системи державного аудиту, потрібно вдосконалити правові засади його діяльності та методологічне забезпечення шляхом співпраці з Міжнародною федерацією бухгалтерів та використанням практики ЄC щодо аудиту в державній сорері. Ще одна суттєва проблема, яка вимагає негайного вирішення - кадрове забезпечення ДАСУ, який зараз укомплектована майже повністю з колишніх фрінансових інспекторів, які звикли проводити ревізії. Тобто, потрібно організувати навчання аудиторів та курси підвищення кваліфрікації, можливо, стажування за кордоном. Також, важливо, впроваджувати результати аудиту в діяльність державних підприємств та отримувати економічний ефрект.

Висновки 3 проведеного дослідження. Таким чином, незважаючи на те, що в Україні державний фрінансовий аудит, на відміну від європейських країн, почали використовувати на практиці як складову частину контролю, десять років тому, коли весь сучасний світ уже створив та використовував систему аудиту під час оцінки ефективності діяльності підприємств всіх форм власності, впровадження аудиту має великі перспективи. Аудит відрізняється від ревізії, бо запобігає появі 
порушень та недоліків. Крім цього, аудитори надають рекомендації, які в майбутньому допоможуть керівництву управляти підприємством. Тобто, мета аудиту - профрілактика порушень, а не покарання. На жаль, більшість керівників бюджетних установ не сприймають таку систему. Отже, перед тим, як реформувати систему контролю, обліку або аудиту, необхідно змінити ставлення до ефективності діяльності, знизити рівень фрінансових порушень, недостач та корупційних схем. Керівництво державних підприємств має бути зацікавлено у покращенні показників діяльності. Що стосується методики та порядку проведення аудиту, то необхідно удосконалити вітчизняне законодавство, систему навчання аудиторів високої кваліфрікації, запроваджувати аудити частіше та застосовувати рекомендації на практиці.

\section{БІБЛІОГРАФІЧНИЙ СПИСОК:}

1. Богданів І.О. Успіхи і невдачі державного фрінансового аудиту суб'єктів господарювання. Фінансовий контроль. 2017. № 4 (51). С. 25-32.

2. Владімірова Н.П. Напрями рефрормування державного фінансового контролю задля забезпечення фрінансової безпеки суб'єктів господарювання. Економічна наука. Інвестиції: практика та досвід. 2016. № 16. C. 46-52.

3. Звіт ДАСУ за результатами діяльності за 2017/2018 роки. URL: http://www.dkrs.gov.ua (дата звернення: 10.11.2019).

4. Магута Р.М. Напрями вдосконалення державного фрінансового контролю в Україні. Економічна наука. Економіка і держава. 2012. № 11. С. 94-97.

5. Мних Є.М. Державний фрінансовий аудит : методологія і організація. Серія «Облік і фрінанси». 2015. Випуск 9 (33).Ч. 3. С. 419-426.

6. Письменна Т.В. Теоретичні засади державного фінансового контролю: вітчизняний і зарубіжний досвід. Світ фрінансів. 2008. № 4. С. 130-138.

7. Пушкарьова О.Ю. Державний фрінансовий аудит суб'єктів господарювання як пріоритетний напрямок діяльності органів державної контрольноревізійної служби. Держава та регіони. Серія «Економіка та підприємництво». 2009. № 7. С. 160-164.

8. Пушкарьова О.Ю. Проблеми співіснування двох видів державного фрінансового контролю: інспектування та державного фрінансового аудиту. KHEY. 2017.

9. Репетько О.О. Пріоритетні напрями розвитку фрінансового аудиту в сучасних умовах України. Механізми державного управління. Вісник Національної академії державного управління. 2016. № 2. C. 119-127.

10. Сотник О.Г. Особливості нормативно-правового регулювання державного аудиту в Україні та напрями його вдосконалення. Управління розвитком. 2011. № 2 (99). С. 173-175.

11. Шевчук О.Д., Мукоїд І.Л. Особливості проведення державного аудиту в Україні. Збірник наукових праць ВНАУ. Серія «Економічні науки». 2014.№ 4 (70). C. 230-234.

\section{REFERENCES:}

1. Bogdanov I. O. (2017) Uspikhy i nevdachi derzhavnoho finansovoho audytu subiektiv hospodariuvannia [Successes and failures of the state financial audit of economic entities]. Finansovyi kontrol. [Financial control], no. 4 (51). pp. 25-32.

2. Vladimirova N. P. (2016) [Areas of reforming state financial control to ensure the financial security of business entities]. Ekonomichna nauka. Investytsii: praktyka ta dosvid. [Economics. Investment: practice and experience], no. 16, pp. 46-52.

3. Zvit DASU za rezultatamy diialnosti za 2017/2018 roky [SASU activity report for 2017/2018]. URL: http:// www.dkrs.gov.ua (accessed 10 November 2019).

4. Maguta R. M. (2012) Napriamy vdoskonalennia derzhavnoho finansovoho kontroliu v Ukraini. [Areas of improvement of the state financial control in Ukraine]. Ekonomichna nauka. Ekonomika i derzhava [Economics. Economy and the state]. No. 11. pp. 94-97 (in Ukrainian).

5. Mnykh E. M. (2015) Derzhavnyi finansovyi audyt : metodolohiia i orhanizatsiia. [State financial audit: methodology and organization]. Seriia "Oblik i finansy". [Accounting and Finance Series], vol. 9 (33), no. 3, pp. 419-426.

6. Pysmenna T. V. (2008) Teoretychni zasady derzhavnoho finansovoho kontroliu: vitchyznianyi i zarubizhnyi dosvid [Theoretical principles of state financial control: domestic and foreign experience]. Svit finansiv. [The world of finance], no. 4, pp. $130-138$.

7. Pushkaryova O. Yu. (2009) Derzhavnyi finansovyi audyt subiektiv hospodariuvannia yak priorytetnyi napriamok diialnosti orhaniv derzhavnoi kontrolno-reviziinoi sluzhby [State financial audit of economic entities as a priority area of activity of bodies of state control and audit service]. Derzhava ta rehiony. Seriia "Ekonomika ta pidpryiemnytstvo". [State and regions. Economy and Entrepreneurship series], no. 7, pp. 160-164.

8. Pushkaryova A.Y. (2017) Problemy spivisnuvannia dvokh vydiv derzhavnoho finansovoho kontroliu: inspektuvannia ta derzhavnoho finansovoho audytu [Problems of coexistence of two types of state financial control: inspection and state financial audit] KNEU. (in Ukrainian).

9. Repetko O. O. (2016) Priorytetni napriamy rozvytku finansovoho audytu $v$ suchasnykh umovakh Ukrainy. [Priority directions of financial audit development in modern conditions of Ukraine]. Mekhanizmy derzhavnoho upravlinnia. Visnyk Natsionalnoi akademii derzhavnoho upravlinnia [Mechanisms of public administration. Bulletin of the National Academy of Public Administration], no. 2, pp. 119-127.

10. Sotnik O. G. (2011) Osoblyvosti normatyvnopravovoho rehuliuvannia derzhavnoho audytu v Ukraini ta napriamy yoho vdoskonalennia. [Features of legal regulation of state audit in Ukraine and directions of its improvement]. Upravlinnia rozvytkom. [Development Management], no. 2 (99). pp. 173-175.

11. Shevchuk O. D., Mukhoid I. L. (2014) Osoblyvosti provedennia derzhavnoho audytu $v$ Ukraini [Features of conducting state audit in Ukraine]. Zbirnyk naukovykh prats VNAU. Seriia "Ekonomichni nauky". [Collection of scientific works of VNAU. Economic Sciences Series], no. 4 (70), pp. 230-234. 
Savchenko Alla

Candidate of Economic Sciences, Associate Professor, Senior Lecturer at Department of Audit and Economic Analysis University of State Fiscal Service of Ukraine

Poliakov Vadym

Student

Institute of Accounting, Analysis and Audit University of State Fiscal Service of Ukraine

\section{CURRENT SITUATION AND PROSPECTS OF DEVELOPMENT OF THE STATE FINANCIAL AUDIT OF ACTIVITIES OF PUBLIC ECONOMY SECTOR}

The purpose of the article. To analyze the current state, procedure of implementation, problems and prospects of development of the state financial audit in the activity of SASU. There are many state-owned enterprises and institutions in Ukraine. The vast majority are ineffective or in liquidation. They require funding from the state budget, but the appropriateness and efficiency of the use of funds requires the operation of a highquality and up-to-date financial control system, of which the state financial audit is an integral part.

Methodology. The State Audit Office of Ukraine (SASU) is a body of executive power that implements the state policy in the field of financial control. The purpose of the audit is to verify the legality and efficiency of the use of public resources. It is used to check and analyze the indicators of financial, operational and economic activity, that is, the object of audit - a state-owned enterprise that receives funds from the budget.

In today's market economy, the importance of public financial audit is increasing, which contributes to improving the efficiency of government institutions, the use of budget funds and improving the management system.

The methodological features of the audit of budgetary enterprises are, first and foremost, to examine the risk factors associated with the use of budgetary funds. In addition, each risk factor should be investigated for compliance with the legislative acts, their validity and feasibility are revealed, and the planned indicators are compared with the actual ones.

The auditor should then determine the degree of impact of the irregularities on the financial and economic activities. In doing so, it is important for the auditor to identify external and internal risk factors.

In order to determine the priority areas for improving the state audit procedure, it is first necessary to analyze its current state and identify the positive and negative trends in the activity of the Audit Service.

Results. The system of management of public institutions is inefficient, does not meet the requirements of the national economy and does not fulfill the social and strategic functions entrusted to it, and therefore needs reforming. The main task of financial audit is to help the company to keep records properly and efficiently and appropriately use the state budget funds. The main directions of reforming the audit system of budgetary institutions: formation of new and improvement of existing methods of control and improvement of organizational structures of financial audit.

An audit is different from an audit because it prevents irregularities and weaknesses. In addition, auditors provide guidance that will help management manage the business in the future. That is, the purpose of the audit is to prevent violations, not punishments. Unfortunately, most budget executives do not accept this system. Therefore, before reforming the system of control, accounting or audit, it is necessary to change the attitude to the efficiency of activities, reduce the level of financial irregularities, shortages and corruption schemes. The management of state-owned enterprises should be interested in improving performance.

Regarding the methodology and procedure for conducting the audit, it is necessary to improve the national legislation, the system of training of high-quality auditors, introduce audits more often and apply the recommendations in practice.

Scientific novelty of the results obtained. It is to substantiate theoretical and methodological support and practical proposals for further reform of state financial control in the context of ensuring the financial security of economic entities.

Value/originality. The practical significance of the results of the work is to provide recommendations, substantiated theoretical provisions and to provide scientific and methodological approaches and provisions for the reform of the SCF. 